\title{
Factors Affecting the Biosynthesis of L-Tryptophan by Genetically Modified Strains of Escherichia coli
}

\author{
By GUNNAR S. SKOGMAN* AND JAN-ERIC SJÖSTRÖM \\ $A C$ Biotechnics $A B, B o x$ 4, S-232 00 Arlöv, Sweden
}

(Received 30 April 1984; revised 20 June 1984)

\begin{abstract}
Derivatives of Escherichia coli strain W3110 with increased tryptophan synthase (TS) activity were constructed. The biosynthesis of serine was shown to limit tryptophan production in minimal medium with indole as precursor. In the presence of serine and indole we obtained a correlation between the specific activity of TS and the specific productivity $\left(q_{\mathrm{p}}\right)$ of tryptophan. Supplementation of the growth medium with glycine enhanced $q_{\mathrm{p}}$ two-fold. In a strain with high serine hydroxymethyltransferase (SHMT) activity no such increase of tryptophan productivity was observed, although crude extracts from these cells were shown to produce tryptophan with indole, one-carbon units and glycine as precursors. Growth of the strain with high SHMT activity was inhibited in a medium with high glycine concentration. This inhibition could not be released by addition of isoleucine and valine. In a buffer system with permeabilized cells high in specific TS and SHMT activities we did not obtain any tryptophan production in presence of indole, glycine, one-carbon units and cofactors. On the other hand, in a buffer system with indole and serine as precursors we obtained high $q_{\mathrm{p}}$ of tryptophan [13.3 $\mathrm{g}$ tryptophan (g dry wt cells $)^{-1} h^{-1}$, which was correlated to the TS specific activity.
\end{abstract}

\section{INTRODUCTION}

Different methods have been described to obtain overproduction of tryptophan by genetically modified strains of Escherichia coli, either from cells grown in a minimal medium (Tribe \& Pittard, 1979), or in a minimal medium supplemented with a precursor of tryptophan (Aiba et al., 1982). Bang et al. (1983a) have described production of tryptophan in a buffered system with resting cells and continuous production by immobilized cells of $E$. coli in the presence of precursors (Bang et al., 1983b). Another method for tryptophan production has been studied by Decottignies-Le Maréchal et al. (1979) where indole, ammonia and pyruvate were converted by immobilized $E$. coli cells induced for the expression of tryptophanase (EC 4.1.99.1). However, there are few or no reports on attempts to increase tryptophan synthesis by the addition of metabolites such as serine, glycine or formate to growing cells, or by the amplification of genes affecting serine biosynthesis.

In the last step of tryptophan biosynthesis, serine and indoleglycerol phosphate are condensed by the enzyme tryptophan synthase (TS; EC 4.2.1 .20) (Smith \& Yanofsky, 1962). Serine is also a precursor of cysteine and supplies one-carbon units for the biosynthesis of purines, methionine, thymidylate and $N$-formylmethionyl tRNA by the folate pathway. The formation of one-carbon units is catalysed by serine hydroxymethyltransferase (SHMT; EC 2.1.2.1) by which serine is converted to glycine and $N^{5}, N^{10}$-methylenetetrahydrofolate (Deu \& Harvey, 1982; Harvey, 1973; Pizer, 1965). SHMT also catalyses the reverse reaction when exogenous glycine is provided. This property has been utilized in the fermentative production of serine (Izumi et al., 1982; Omori et al., 1983). Another source of one-carbon units in E. coli is from glycine, via

Abbreviations: PALP, pyridoxal 5'-phosphate; PDAB, 4-dimethylaminobenzaldehyde; SHMT, serine hydroxymethyltransferase; TS, tryptophan synthase. 
the glycine cleavage enzyme system (Meedel \& Pizer, 1974; Plamann et al., 1983). The conversion of glycine to serine occurs in prototrophic strains only when glycine is used as nitrogen source (Newman et al., 1974; Newman \& Walker, 1982). A third possible pathway from formate has been described (Cheesman \& Crosbie, 1966; Crosbie, 1966; Newman, 1970). In E. coli K12, glycine can be used as nitrogen or carbon source (Newman et al., 1976) but serine cannot be used as the sole carbon source (Newman et al., 1981).

Serine is known to inhibit cell growth transiently. This inhibiton is reversed by leucine or isoleucine and valine, probably by inducing L-serine deaminase (EC 4.2.1.13) (Cosloy \& McFall, 1970 ; Newman \& Walker, 1982) and by supplying isoleucine which is limiting in $E$. coli cells grown in the presence of serine (Uzan \& Danchin, 1978). The E. coli glyA gene, encoding SHMT, has been cloned and strains harbouring multicopy plasmid vectors carrying the $g l y A$ gene were shown to overproduce the enzyme 17-26-fold (Stauffer et al., 1981). The control of this enzyme seems to be complex (Greene \& Radovich, 1975; Miller \& Newman, 1974) and the mechanism by which the glycine operon is regulated is not clearly understood (Stauffer, 1983).

In this report we describe the effects of different precursors such as indole, serine, glycine and one-carbon units on the biosynthesis of tryptophan in growing cultures, in crude extracts and in a buffer system with resting cells. The precursor effect on cell growth, enzyme activities (TS and SHMT) and the specific productivity $\left(q_{\mathrm{p}}\right)$ of tryptophan were studied in derivatives of $E$. coli W3110 with genetic alterations in the biosynthetic pathways for tryptophan and glycine.

\section{METHODS}

The derivatives of E. coli strain W3110 and the plasmids used in this study are listed in Table 1 . The strains were made tna by $\mathrm{P} 1$ transduction with strain $\mathrm{JC} 12704$ carrying the tna300::Tn10 allele described by Ream et al. (1980). Tetracycline sensitive tha clones were isolated after penicillin enrichment. Strain ACB1 was constructed by transduction of strain W3110 with phage P1 lysate propagated on a derivative of W3110 that had an anthranilate synthase insensitive to feedback inhibition by L-tryptophan. This strain was a gift from C. Yanofsky, Department of Biological Sciences Stanford University, Calif., USA. Strain ACB2 was a spontaneous mutant of ACB1 with increased resistance to 5-methyl-DL-tryptophan. The $\operatorname{trp} R$ genotype was established by the high cotransduction frequency $(70 \%)$ between 5-methyl-DL-tryptophan resistance and the threonine marker in transductions with strain $\mathrm{C} 600$ ( $t h r l e u$ ) as recipient. The strains $\mathrm{C} 600, \mathrm{JC} 12704$ and phage $\mathrm{P} 1$ were obtained from the culture collection at the Department of Microbiology, Umeå University, Sweden.

Media and growth conditions. The basal medium used was M9 (Miller, 1972) with $0.4 \%$ glucose. The complex medium used was LB, described by Bertani (1951). All media were solidified by addition of $1.5 \%(\mathrm{w} / \mathrm{v})$ agar. Supplements (glycine, L-serine, formate and cofactors) were added separately. For selection of antibiotic resistant bacteria, ampicillin $\left(50 \mu \mathrm{g} \mathrm{ml}^{-1}\right)$ or tetracycline $\left(10 \mu \mathrm{g} \mathrm{ml}^{-1}\right)$ were added. Indole (Merck), used as a precursor for L-tryptophan synthesis, was dissolved in ethanol and added to a final concentration of about $80 \mu \mathrm{g} \mathrm{ml}^{-1}$. Cultures were grown at $37^{\circ} \mathrm{C}$ in a shaking water bath. The optical density of growing cultures was determined at $620 \mathrm{~nm}$. $\mathrm{OD}_{620} / 3 \cdot 2$ is the dry weight $\left(\mathrm{g}^{-1}\right)$.

Preparation of competent cells and plasmid DNA isolation. Preparation of competent cells and transformation followed the procedure of Cohen et al. (1972). For isolation of plasmid DNA the cleared lysate method of Birnboim \& Doly (1979) and CsCl/ethidium bromide density gradients according to Kupersztoch \& Helinski (1973) were used.

Construction of plasmid pSGS14. Plasmid pSGS14 was constructed by insertion of an $8.7 \mathrm{~kb}$ Eco R1 fragment carrying the tryptophan operon from plasmid pSGS4 (13.1 kb, Table 1) into plasmid pGS29 (Table 1). DNA (1 $\mu \mathrm{g}$ ) from plasmid pGS29 and pSGS4 was digested with EcoR1 (BioLabs New England) in $10 \mu 1100 \mathrm{~mm}-\mathrm{Tris} / \mathrm{HCl}$ (pH 7.5), $6 \mathrm{mM}-\mathrm{MgCl}_{2}, 1 \mathrm{mM}$-DTT, $100 \mu \mathrm{g} \mathrm{BSA} \mathrm{ml}{ }^{-1}, 50 \mathrm{mM}-\mathrm{NaCl}$ for $1 \mathrm{~h}$ and then heated to $65^{\circ} \mathrm{C}$ for $5 \mathrm{~min} ; 1 \mu \mathrm{l}$ $200 \mathrm{~mm}$-Tris/ $\mathrm{HCl}$ (pH 7.6), $100 \mathrm{mM}-\mathrm{MgCl}_{2}, 100 \mathrm{mM}$-DTT, $6 \mathrm{mM}$-ATP, $20 \mathrm{mM}$-spermidine, $100 \mu \mathrm{g} \mathrm{BSA} \mathrm{ml}{ }^{-1}$ was then added together with T4 DNA ligase (Boehringer). The ligation mixture was incubated at $15^{\circ} \mathrm{C}$ for $12 \mathrm{~h}$. Competent W3110 trp tna cells $(200 \mu \mathrm{l})$ were transformed with $2 \mu \mathrm{l}$ ligated DNA mixture and prototrophic ampicillin-resistant clones were selected. Several of the clones obtained were analysed by agarose gel electrophoresis on horizontal agarose slab gels in $20 \mathrm{~mm}$-sodium acetate, $1 \mathrm{~mm}$-EDTA, $33 \mathrm{~mm}$-Tris/ $\mathrm{HCl}(\mathrm{pH} 7 \cdot 8$ ). One of the clones contained a $15.7 \mathrm{~kb}$ plasmid (pSGS14) and was chosen for further studies.

Preparation of cell-free extracts. Cultures for enzyme assays were grown overnight at $37^{\circ} \mathrm{C}$ in $\mathrm{M} 9$ medium with or without antibiotic selection, depending on the strain used. Cells were harvested and washed in $100 \mathrm{~mm}$ Tris/ $\mathrm{HCl}(\mathrm{pH} 7.8)$ by centrifugation at $12000 \mathrm{~g}$ for $10 \mathrm{~min}$. Cells resuspended and chilled in the same buffer were sonicated in a MSE Soniprep 150 for $2 \mathrm{~min}$ (six times $20 \mathrm{~s}$ with $20 \mathrm{sinterruptions).} \mathrm{The} \mathrm{extracts} \mathrm{were} \mathrm{centrifuged} \mathrm{at}$ $17000 \mathrm{~g}$ for $20 \mathrm{~min}$ and then immediately used for enzyme assays.

Tryptophan synthase assay. TS was measured in a reaction mixture containing $100 \mathrm{mM}-\mathrm{Tris} / \mathrm{HCl}(\mathrm{pH} 7.8)$, 
Table 1. E. coli strains and plasmids used

\begin{tabular}{|c|c|c|}
\hline Bacterial strains & Genotype/phenotype $\uparrow$ & Source or reference \\
\hline W3110 & & $\begin{array}{l}\text { B. Bachmann, E. coli Genetic Stock } \\
\text { Center, Yale University }\end{array}$ \\
\hline $\mathrm{ABC1}$ & $\operatorname{tna} \operatorname{trp} E^{*}$ & This laboratory \\
\hline $\mathrm{ACB} 2$ & tha trp $E^{*} \operatorname{trp} R$ & This laboratory \\
\hline $\mathrm{ABC} 3$ & tha trp & This laboratory \\
\hline
\end{tabular}

Plasmids

$\begin{array}{lll}\text { pSGS4 } & \mathrm{Ap} \text {, }, \text { trpEA } A^{+} & \text {Skogman } \text { et al. }(1983) \\ \text { pSGS14 } & \mathrm{Ap}^{\mathrm{r}}, \text { trpE} A^{+} \text {gly } A^{+} & \text {This paper } \\ \text { pGS29 } & \mathrm{Ap}^{\mathrm{r}}, \text { gly } A^{+} & \text {Stauffer } \text { et al. }(1981)\end{array}$

$\dagger$ The anthranilate synthase encoded by $\operatorname{trp} E^{*}$ is insensitive to feedback inhibition.

$80 \mathrm{mM}$-L-serine, $180 \mathrm{~mm}-\mathrm{NaCl}, 30 \mathrm{mM}$-pyridoxal $5^{\prime}$-phosphate (PALP) (Merck) and $5 \mu \mathrm{g}$ indole in a total volume of $500 \mu \mathrm{l}$. Enzyme and buffer, total volume $100 \mu \mathrm{l}$, were added and the mixture was incubated for $20 \mathrm{~min}$ at $37^{\circ} \mathrm{C}$. The reaction was stopped by transferring $50 \mu \mathrm{l}$ of the mixture to $5 \mathrm{ml}$ of cold methanol and the unreacted indole was determined. One $\mathrm{ml}$ of 4-dimethylaminobenzaldehyde (PDAB) (Merck) $\left(6 \%\right.$ in $\left.1.5 \mathrm{M}-\mathrm{H}_{2} \mathrm{SO}_{4}\right)$ was added. The tubes were incubated for $20 \mathrm{~min}$ at $40{ }^{\circ} \mathrm{C}$ and the absorbance was determined at $525 \mathrm{~nm}$. Indole concentrations were estimated from a standard. One unit of TS catalyses the reaction of $0.1 \mu \mathrm{mol}$ indole in $20 \mathrm{~min}$ at $37^{\circ} \mathrm{C}(\mathrm{Smith}$ \& Yanofsky, 1962).

Serine hydroxymethyltransferase assay. SHMT was determined by the method described by Scrimegeour \& Huennekens (1962). One unit of activity is defined as the amount of enzyme which catalyses the disappearance of $1.0 \mu \mathrm{mol} \mathrm{HCHO} \min ^{-1}$ at $37^{\circ} \mathrm{C}$ under those conditions.

Protein determination. Protein was determined by the method of Lowry, with bovine serum albumin as standard.

Determination of L-tryptophan. Samples of $100 \mu \mathrm{l}$ of cell-free extract were mixed with $1.0 \mathrm{ml}$ PDAB [15 mg

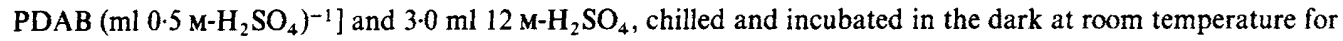
$1 \mathrm{~h}$. To this, $300 \mu \mathrm{NaNO}_{2}\left(400 \mu \mathrm{g} \mathrm{ml}^{-1}\right)$ was added and after $30 \mathrm{~min}$ in the dark the absorbance was read at $600 \mathrm{~nm}$ (Spies \& Chambers, 1948). The concentration of L-tryptophan was determined from a standard. Alternatively, L-tryptophan was determined by HPLC using a Varian Model 5020 with a C18-column (Nucleosil) and $\mathrm{H}_{2} \mathrm{O} /$ methanol $(80: 20, \mathrm{v} / \mathrm{v}) \mathrm{pH} 6 \cdot 0$ as eluant.

Determination of specific productivity. Indole $\left(80 \mu \mathrm{g} \mathrm{ml}^{-1}\right)$ was added to bacteria $\left(\mathrm{OD}_{620}=0 \cdot 5-0 \cdot 7\right)$ in $\mathrm{M} 9$ medium supplemented with ampicillin or tetracycline and the cultures were incubated at $37^{\circ} \mathrm{C}$. Samples were taken at zero time and after different periods of incubation. The consumption of indole and cell growth were followed. Indole was determined by the procedure described for TS and cell growth was measured at $620 \mathrm{~nm}$. There was $100 \%$ conversion of indole to L-tryptophan and the specific tryptophan productivity $\left(q_{\mathrm{p}}\right)$ is expressed as $\mathrm{g}$ tryptophan ( $\mathrm{g}$ dry wt cell) $)^{-1} \mathrm{~h}^{-1}$. The mean dry weight was used for the period studied.

Conversion of glycine and indole to L-tryptophan in a cell-free extract or with permeabilized cells. The enzymic synthesis of L-tryptophan was studied in a buffered system containing $1.0 \mathrm{ml} 50 \mathrm{~mm}$-potassium phosphate buffer pH 7.5, $50 \mathrm{~mm}$-glycine, $2.5 \mathrm{mM}-\mathrm{HCHO}, 0.03 \mathrm{~mm}$-PALP, $300 \mu \mathrm{g}$ tetrahydrofolate, $10 \mu \mathrm{g}$ indole and $500 \mu \mathrm{l} \mathrm{H}_{2} \mathrm{O}$. Cell-free extract and/or buffer to a volume of $200 \mu \mathrm{l}$ was added and the mixture was incubated at $37^{\circ} \mathrm{C}$; samples were withdrawn at different times for indole and L-tryptophan analysis. When permeabilized cells were studied $200 \mu \mathrm{l}$ of cells was added to the mixure above containing $0 \cdot 1 \%$ Triton X-100.

Production of L-tryptophan in a high production system. L-Tryptophan production was studied in the system described by Bang et al. (1983a). The strains ACB1(pSGS4) and ACB1(pSGS14) were grown in M9 minimal medium with $10 \mu \mathrm{g}$ tetracycline $\mathrm{ml}^{-1}$ and strain ACB2(pSGS4) was grown in M9 minimal medium with $0.2 \%$ Casamino acids and $10 \mu \mathrm{g}$ tetracycline $\mathrm{ml}^{-1}$. The cells were grown overnight, harvested and washed twice in $0.9 \%$ $\mathrm{NaCl}$. Cells $(0 \cdot 2-0 \cdot 3 \mathrm{~g}$ wet wt) were resuspended in $20 \mathrm{ml} 0 \cdot 1 \mathrm{M}$-potassium phosphate buffer $(\mathrm{pH} 8 \cdot 0)$. Indole $(0.2 \mathrm{~g})$, L-serine $(0.2 \mathrm{~g})$, PALP $(0.2 \mathrm{mg})$ and Tween 80 (final concentration $1 \%$, were added. The mixture was incubated at $37^{\circ} \mathrm{C}$ and samples were withdrawn for determination of L-tryptophan at different times.

\section{RESULTS}

Tryptophan synthase activity in different W3110 derivatives

In order to study overproduction of tryptophan in growing and resting cells, different derivatives of strain W3110 were constructed. The TS activity and the specific productivity were determined. The specific TS activity in strain ACBl was $4 \mathrm{U}$ (mg protein) ${ }^{-1}$ when grown in a 
Table 2. Tryptophan synthase specific activity, and $q_{p}$ of tryptophan in derivatives of strain W3110

Organisms were grown in M9 medium supplemented with tryptophan $\left(300 \mu \mathrm{g} \mathrm{ml}^{-1}\right)$ or Casamino acids (Difco; $0.2 \%$ ) as indicated. Each experiment was repeated four times with essentially identical results.

\begin{tabular}{|c|c|c|c|c|}
\hline Strain & Plasmid & Supplements & $\begin{array}{c}\text { TS sp. act. } \\
{\left[\mathrm{U}(\mathrm{mg} \text { protein })^{-1}\right]}\end{array}$ & $\frac{q_{\mathrm{p}}}{\left[\mathrm{g} \operatorname{Trp}(\mathrm{g} \text { dry } \mathrm{wt})^{-1} \mathrm{~h}^{-1}\right]}$ \\
\hline ACB 1 & 一 & - & 4 & 0.016 \\
\hline ACB1 & - & Trp & 2 & 0.010 \\
\hline $\mathrm{ACB} 2$ & 一 & - & 10 & 0.028 \\
\hline $\mathrm{ACB} 2$ & - & Trp & 11 & $0 \cdot 028$ \\
\hline $\mathrm{ACB} 1$ & pSGS4 & - & 80 & 0.15 \\
\hline ACB1 & pSGS4 & Trp & 48 & $0 \cdot 10$ \\
\hline ACB2 & pSGS4 & Casa & 120 & 0.22 \\
\hline $\mathrm{ACB} 2$ & pSGS4 & Casa + Trp & 125 & $0 \cdot 22$ \\
\hline
\end{tabular}

Table 3. $q_{p}$ of tryptophan in derivatives of strain W3110 grown in M9-medium supplemented with serine

The specific activity of TS was $10 \mathrm{U}$ (mg protein) ${ }^{-1}$ for strain ACB2 and $100 \mathrm{U}$ (mg protein $)^{-1}$ for strain ACB2(pSGS4). Each experiment was repeated four times, with essentially identical results.

$\begin{array}{ccc}\begin{array}{c}\text { Serine concn } \\ \left(\mathrm{mg} \mathrm{ml}^{-1}\right)\end{array} & \overbrace{\text { ACB2 }}^{\text {ACB2(pSGS4) }} \\ 0 & 0.029 & 0.13 \\ 0 & 0.16 & 0.78 \\ 0.1 & 0.25 & 1.04 \\ 0.5 & 0.26 & 1.20 \\ 1.0 & 0.25 & 1.32 \\ 2.5 & 0.28 & 1.42 \\ 5.0 & \end{array}$

tryptophan-free medium. In strain ACB2 (trpR) the activity was about $10 \mathrm{U}$ (mg protein) $)^{-1}$. When plasmid pSGS4 was introduced into strain ACB1 the specific activity was increased 20fold. However, in the presence of tryptophan, the activity decrease to $50-60 \%$ of that obtained in absence of tryptophan. In the trpR strain, ACB2, carrying plasmid pSGS4, the TS activity was $120 \mathrm{U}$ (mg protein) $)^{-1}$ and was not affected by tryptophan addition (Table 2). The $q_{\mathrm{p}}$ of tryptophan was 10-fold higher in strain ACB1(pSGS4) as compared with the plasmid-free derivative grown under identical conditions. When pSGS4 was introduced into strain ACB2 the $q_{\mathrm{p}}$ was $0.22 \mathrm{~g}$ tryptophan (g dry wt cells) $)^{-1} \mathrm{~h}^{-1}$. This $q_{\mathrm{p}}$ in strain ACB2(pSGS4) may to some extent have been affected by the serine in the Casamino acids. There was no linear correlation between enzyme activities and specific productivities, although an increase in TS activity always led to a higher $q_{\mathrm{p}}$.

\section{Tryptophan specific productivity in the presence of serine}

In order to determine if the amount of serine synthesized from glucose limited tryptophan biosynthesis, M9 medium was supplemented with different concentrations of serine and the $q_{\mathrm{p}}$ was determined in strain ACB2(pSGS4). This strain showed the highest TS activity and $q_{\mathrm{p}}$ (Table 2). Table 3 shows that at a TS activity of $10 \mathrm{U}$ (mg protein) $)^{-1}$ (strain ACB2) we obtained an 8-10fold increase in the $q_{\mathrm{p}}$ at $0.5 \mathrm{mg}$ serine $\mathrm{ml}^{-1}$. Further additions of serine did not result in any increase. For strain ACB2(pSGS4) with a specific activity of $100 \mathrm{U}$ (mg protein) ${ }^{-1}$ we also obtained a 10 -fold increase in $q_{\mathrm{p}}$ from 0.13 to $1.42 \mathrm{~g}$ tryptophan (g dry wt cells) ${ }^{-1} \mathrm{~h}^{-1}$ but $q_{\mathrm{p}}$ still increased at $5 \mathrm{mg}$ serine $\mathrm{ml}^{-1}$. Thus addition of serine drastically increased the specific productivity. 


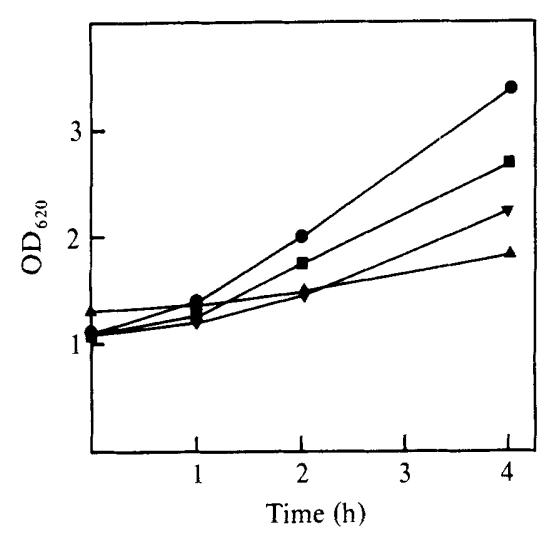

Fig. 1

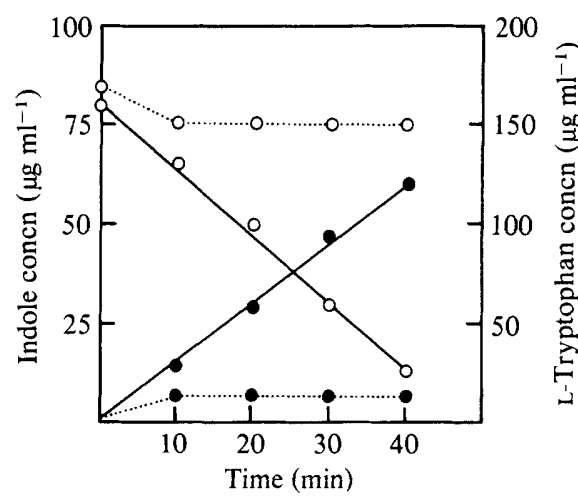

Fig. 2

Fig. 1. Effect of indole and L-serine on growth of E. coli strain ACB1(pSGS4). The organism was grown at $37^{\circ} \mathrm{C}$ in the following media. M9 medium; $\mathbf{\square}, \mathrm{M} 9$ medium + indole $\left(0.08 \mathrm{mg} \mathrm{ml}^{-1}\right) ; \boldsymbol{\Lambda}, \mathbf{M} 9$ medium $+\mathrm{L}$-serine $\left(1 \mathrm{mg} \mathrm{m}^{-1}\right) ; \boldsymbol{\nabla}, \mathrm{M} 9$ medium + indole $\left(0.08 \mathrm{mg} \mathrm{ml}^{-1}\right)$ and $\mathrm{L}$-serine $\left(1 \mathrm{mg} \mathrm{ml}^{-1}\right)$.

Fig. 2. Time course of the formation of L-tryptophan $(O)$ and indole consumption $(O)$ by cell-free extracts of $E$. coli strains ACB1(pSGS4) (........) and ACB1(pSGS14) (-) in a buffered system containing glycine, formaldehyde, PALP and tetrahydrofolate.

Table 4 Specific activity of serine hydroxymethyltransferase and tryptophan synthase in derivatives of strain $A C B I$

Organisms were grown in M9 medium supplemented with glycine $\left(4 \mathrm{mg} \mathrm{l}^{-1}\right)$ as indicated. Each experiment was repeated four times, with essentially identical results.

\begin{tabular}{|c|c|c|c|}
\hline \multirow[b]{2}{*}{ Strain } & \multirow[b]{2}{*}{ Supplement } & \multicolumn{2}{|c|}{$\begin{array}{l}\text { Enzyme sp. act. } \\
{\left[\mathrm{U}(\mathrm{mg} \text { protein })^{-1}\right]}\end{array}$} \\
\hline & & SHMT & TS \\
\hline $\mathrm{ACB} 1(-)$ & - & 0.010 & 4 \\
\hline $\mathrm{ACB} 1$ (pSGS4) & - & 0.011 & 80 \\
\hline $\mathrm{ACB} 1$ (pSGS14) & - & 0.17 & 69 \\
\hline ACB1 (pSGS14) & Gly & 0.06 & 69 \\
\hline
\end{tabular}

Effect of indole and serine on cell growth

Since the precursors serine and indole inhibit cell growth at high concentrations (Bang et al., $1983 a$; Cosloy \& McFall, 1970) we studied the effect of serine and/or indole on growth of the tryptophan producing strain ACB1 carrying plasmid pSGS4. At $80 \mu \mathrm{g}$ indole and $1 \mathrm{mg}$ serine $\mathrm{ml}^{-1}$, cell growth was affected (Fig. 1). The degree of inhibition was dependent on the precursor concentration (data not shown). As reported by Uzan \& Danchin (1978) the serine inhibition could be reversed by addition of valine and isoleucine (data not shown). A partial increase in cell growth was obtained when strain ACB1(pSGS4) was grown in a medium supplemented with both indole and serine (Fig. 1).

\section{Specific activity of SHMT and TS in strain ACBI(pSGS14)}

The conversion of serine to glycine by SHMT is reversible in the presence of one-carbon units (Scrimgeour \& Huennekens, 1962). We therefore tried to replace serine by addition of glycine to growing cells. In order to increase the amount of SHMT we constructed a recombinant plasmid, pSGS14, containing both the $g l y A$ gene and the tryptophan operon, as described in Methods. The results (Table 4) show a 10-15-fold enhancement in specific activity of SHMT. The level of TS in strain ACB1(pSGS14) was somewhat lower compared with strain ACB1(pSGS4). In the presence of glycine $\left(4 \mathrm{mg} \mathrm{ml}^{-1}\right)$ there was repression of SHMT: the specific activity was reduced to $40 \%$. 

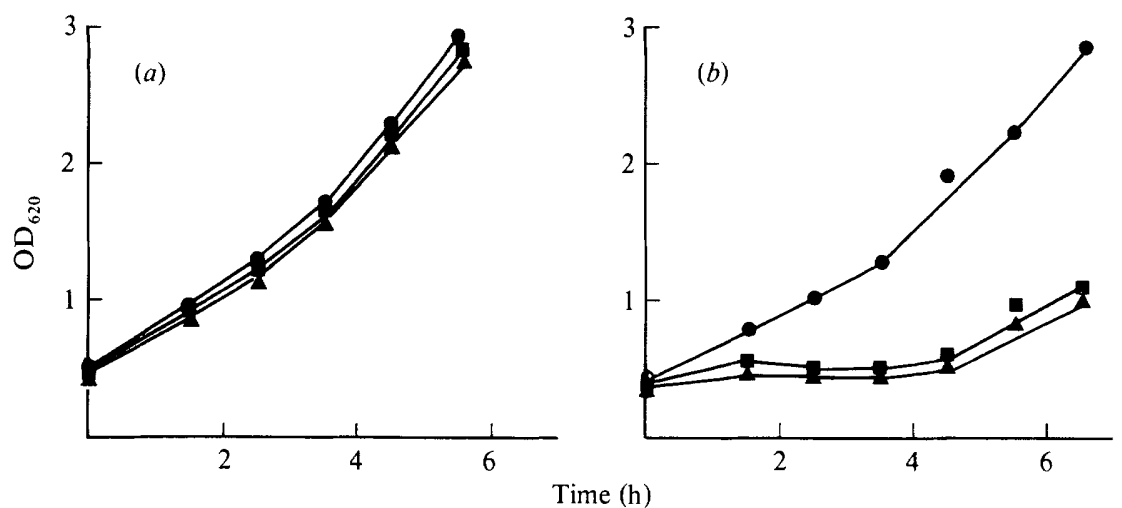

Fig. 3. Effect of glycine on cell growth of E. coli strains ACB1(pSGS4) (a) and ACB1(pSGS14) (b). The cells were grown at $37^{\circ} \mathrm{C}$ in $\mathrm{M} 9$ minimal medium with the following additions: - none; $\square$, glycine $\left(2 \mathrm{mg} \mathrm{ml}^{-1}\right) ; \boldsymbol{\Delta}$, glycine $\left(2 \mathrm{mg} \mathrm{ml}^{-1}\right)$, L-valine $\left(0 \cdot 1 \mathrm{mg} \mathrm{ml}^{-1}\right)$ and $\mathrm{L}$-isoleucine $\left(0 \cdot 1 \mathrm{mg} \mathrm{ml}^{-1}\right)$.

\section{Table 5. Effect of glycine on tryptophan biosynthesis by Triton X-100 permeabilized cells}

$q_{\mathrm{p}}$ was determined in a buffered system containing glycine, tetrahydrofolate, PALP, indole and HCHO (complete; for details see Methods). Glycine was omitted from the mixture as indicated (incomplete). Each experiment was repeated four times, with essentially identical results.

\begin{tabular}{lcc}
\multicolumn{1}{c}{ Strain } & Reaction mixture & $\begin{array}{c}q_{\mathrm{p}} \\
\text { [g Trp }(\mathrm{g} \text { dry } w)^{-1} \mathbf{h}^{-1} \text { ] }\end{array}$ \\
ACB1 (pSGS4) & Complete & $0 \cdot 041$ \\
ACB1 (pSGS4) & Incomplete & $0 \cdot 043$ \\
ACB1 (pSGS14) & Complete & $0 \cdot 080$ \\
ACB1 (pSGS14) & Incomplete & $0 \cdot 042$
\end{tabular}

\section{Production of tryptophan from glycine, formaldehyde and indole}

Cell-free extract. The ability of strain ACB1(pSGS14) to convert glycine, formaldehyde and indole to tryptophan was investigated in a cell-free extract as described in Methods. The results (Fig. 2) show that in an extract from strain ACBl(pSGS14) (which overproduces both TS and SHMT), glycine, formaldehyde and indole were rapidly converted into tryptophan in the presence of cofactors. In an extract from strain ACB1(pSGS4) with a higher activity of TS (Tables 2 and 4) but with a more than 15-fold lower SHMT activity, a small consumption of indole was obtained only during the first $10 \mathrm{~min}$ of incubation. If either glycine, formaldehyde or tetrahydrofolate was omitted from the reaction mixture no tryptophan production was observed (data not shown). Thus the results clearly show that strain ACBl(pSGS14) has the enzymes required to convert glycine, formaldehyde and indole to tryptophan in the presence of tetrahydrofolate.

Permeabilized cells. We also studied tryptophan production in the same system with cells permeabilized with Triton X-100. Strain ACB1(pSGS14) showed a twofold increase in $q_{\mathrm{p}}$ when glycine was added to the mixture (Table 5). Without glycine addition the $q_{\mathrm{p}}$ was the same as for strain ACB1(pSGS4). We did not obtain any increase in $q_{\mathrm{p}}$ for strain ACB1 (pSGS4) after addition of glycine (Table 5). Addition of formaldehyde and tetrahydrofolate was necessary for tryptophan production (data not shown).

\section{Effect of glycine on cell growth in $M 9$ medium}

Strain ACB1 containing plasmid pSGS4 or pSGS14 was grown in M9 medium supplemented with glycine. Strain ACB1(pSGS4) was not affected by the addition of glycine (Fig. $3 a$ ) but strain ACB1 carrying plasmid pSGS14, which contains the gly $A$ gene, was strongly affected. In the presence of $1 \mathrm{mg}$ glycine $\mathrm{ml}^{-1}$ there was a lag period of about $4 \mathrm{~h}$ before cell growth started, but at a lower rate compared with cells grown in M9 medium (Fig. $3 b$ ). The length of the lag period was dependent on the glycine concentration and we could observe effects at $0.2 \mathrm{mg}$ 


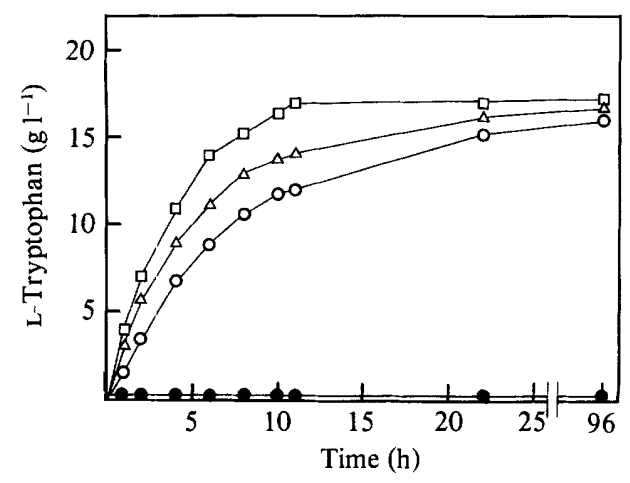

Fig. 4. L-Tryptophan synthesis with resting cells of $E$. coli with different TS activity in a high production system containing indole $\left(10 \mathrm{~g} \mathrm{l}^{-1}\right)$, $\mathrm{L}$-serine $\left(10 \mathrm{~g} \mathrm{l}^{-1}\right)$, pyridoxal phosphate $\left(10 \mathrm{mg}^{-1}\right)$ and Tween $80(1 \%$ ). $\square$, Strain ACB2(pSGS4); $\triangle$, strain ACB1(pSGS4); $O$, strain ACB1(pSGS14); 0 , strain ACB1(pSGS14) in the buffer system with formaldehyde $(5 \mathrm{~mm})$, tetrahydrofolate $\left(0.4 \mathrm{~g} \mathrm{l}^{-1}\right)$, and glycine $\left(10 \mathrm{~g}^{-1}\right)$ instead of $\mathrm{L}$-serine.

\section{Table 6. Effect of glycine and formate on the $q_{p}$ of tryptophan}

Organisms were grown in M9 medium supplemented with glycine $\left(2 \mathrm{mg} \mathrm{m}^{-1}\right)$ or sodium formate $\left(1 \mathrm{mg} \mathrm{ml}^{-1}\right)$ as indicated. Each experiment was repeated four times, with essentially identical results.

\begin{tabular}{|c|c|c|}
\hline Strain & Supplement(s) & {$\left[\mathrm{g} \operatorname{Trp}\left(\mathrm{g}\right.\right.$ dry wt) $\left.{ }^{-1} \mathrm{~h}^{-1}\right]$} \\
\hline ACB1(pSGS4) & - & 0.07 \\
\hline ACB 1 (pSGS4) & Gly & 0.13 \\
\hline $\mathrm{ACB} 1(\mathrm{pSGS} 4)$ & Gly + formate & 0.12 \\
\hline $\mathrm{ACB} \mid(\mathrm{pSGS} \mid 4)$ & - & 0.06 \\
\hline $\mathrm{ACB} 1(\mathrm{pSGS} 14)$ & Gly & 0.06 \\
\hline ACBI(pSGS14) & Gly + formate & 0.06 \\
\hline
\end{tabular}

glycine $\mathrm{ml}^{-1}$ (data not shown). Addition of valine and isoleucine had no effect on the length of the lag period (Fig. $3 b$ ).

\section{Tryptophan specific productivity in the presence of glycine and formate}

Tryptophan could be synthesized in a cell-free extract from strain ACB1(pSGS14) (Fig. 3) in the presence of glycine, formaldehyde, indole and cofactors. We therefore added these compounds, with the exception of cofactors and with formate instead of formaldehyde, to the growth medium and determined the $q_{\mathrm{p}}$ of tryptophan. The results in Table 6 show about a doubling of $q_{\mathrm{p}}$ in the presence of glycine for strain ACB1(pSGS4). This effect did not appear for strain ACB1(pSGS14). We did not obtain any further increase of $q_{\mathrm{p}}$ in the presence of formate. Thus in growing cultures, overproduction of SHMT does not lead to any increase of tryptophan synthesis in the presence of high amounts of glycine or of one-carbon units supplied as formate.

Tryptophan synthesis with permeabilized cells in a high production system

Since both glycine and serine affect cell growth, we studied the $q_{\mathrm{p}}$ of tryptophan in a high production system with non-growing permeabilized cells, as described in Methods.

Although strain ACB1(pSGS14) showed an increased $q_{\mathrm{p}}$ with glycine and indole (Table 5), we could not observe any tryptophan production in this strain in a high production system containing glycine, formaldehyde and tetrahydrofolate (Fig. 4). We next studied tryptophan production in Bang's system (Bang et al., 1983a) with three strains with different TS activities ACB2(pSGS4), ACB1(pSGS4) and ACB1(pSGS14). As shown in Fig. 4, we obtained a rapid conversion of indole to tryptophan. After $6 \mathrm{~h}$ incubation the strains had produced $\left(1^{-1}\right) 14 \mathrm{~g}, 11 \mathrm{~g}$ and $9 \mathrm{~g}$ tryptophan, respectively. Since the same amount of cells was added to each reaction we 
obtained a correlation between specific TS activity and tryptophan production. The $q_{\mathrm{p}}$ of tryptophan decreased during incubation for all three strains. During the first hour of incubation $q_{\mathrm{p}}$ was $13.3 \mathrm{~g}$ tryptophan (g dry wt cells) ${ }^{-1} \mathrm{~h}^{-1}$ for strain ACB2(pSGS4). This value is about 10 -fold higher than that obtained by Bang et al. (1983a) under similar conditions. The yield of tryptophan based on indole was $100 \%$. The rapid decrease in $q_{\mathrm{p}}$ was not dependent on tryptophan degradation since all the strains used lack tryptophanase.

\section{DISCUSSION}

To obtain overproduction of tryptophan by $E$. coli cells grown in a minimal medium supplemented with indole, both serine synthesis and the expression of the $\operatorname{trp} A B$ genes encoding tryptophan synthase have to be increased. We have cloned the tryptophan operon in plasmid pBR322 (Skogman et al., 1983). After transfer of this plasmid into strain W3110 $\operatorname{trp} E^{*}$ tna we obtained a 25 -fold increase of TS activity in the presence of tryptophan. The TS activity was further increased 2.5-fold when the trpR strain ACB2 was used as recipient for plasmid pSGS4. The predicted increase in TS activity in the $\operatorname{trp} R$ strain was higher than that observed. The difficulty we encountered in isolating a stable transformant probably means that the amount of TS in our isolate is lowered either by a trp promotor-down mutation or a decrease in plasmid copy number. Similar difficulties in obtaining stable high copy plasmids harbouring the $\operatorname{trp}$ operon in $\operatorname{trp} R$ strains have been reported (Hersfield et al., 1974; Tsunekawa et al., 1981). To maintain the plasmids in the culture we had to select continuously for tetracycline resistance.

The increase in TS activity resulted in an enhancement of $q_{\mathrm{p}}$ (Table 2), which was not proportional to the increase in TS activity. This suggests that serine is limiting, although the flux through the serine pathway had increased by 20 -fold when the TS activity was increased 60 -fold. By adding serine to the growth medium we have shown that this precursor was still the limiting factor. Addition of $1 \mathrm{mg}$ serine $\mathrm{ml}^{-1}$ to strain ACB2(pSGS4) with the high TS activity, increased $q_{\mathrm{p}}$ sixfold. A further addition of L-serine only resulted in a small increase (Table 3 ).

An alternative way to obtain serine is the conversion of glycine to serine by a glycine cleavage enzyme (Plamann et al., 1983) and SHMT (Meedel \& Pizer, 1974; Newman et al., 1974). Thus we investigated the effect of glycine addition on tryptophan synthesis in strain ACB1(pSGS14) which has an elevated SHMT level. Although this strain has the enzymes to convert glycine and one-carbon units to serine (Fig. 2, Table 5) we failed to obtain any increase in $q_{\mathrm{p}}$ when we added glycine to the growth medium. Growing cells with wild-type activities of SHMT increase tryptophan synthesis twofold. Cells with high SHMT levels were severely affected by the addition of glycine (Fig. $3 b$ ). This growth inhibition was probably not due to overproduction of serine and consequent serine inhibition, since (i) we did not obtain tryptophan production, and (ii) the inhibitory effect could not be relieved with valine and isoleucine. A possible explanation is that in the presence of a high SHMT level the pool of one-carbon units in the cells is rapidly drained since too few one-carbon units are formed by glycine splitting (Meedel \& Pizer, 1974). The high concentration of glycine used is necessary in order to obtain an enhancement of $q_{\mathrm{p}}$ for the wild-type strain. This may be the result of low permeability for glycine (Crosbie, 1966). Since both serine and glycine affected cell growth, we studied tryptophan production in a high production system with non-growing cells.

In the high production system with glycine, formate and tetrahydrofolate, we did not obtain any tryptophan production with strain ACB1 (pSGS14). This may depend on technical problems and oxidative inactivation of tetrahydrofolate rather than on the strain used. With a continuous addition of formaldehyde and tetrahydrofolate it may be possible to synthesize tryptophan. However, the requirement for THF reduces the possibility of developing an economic process. By addition of serine to the high production system we obtained a very rapid formation of tryptophan which was proportional to the TS activity and the $q_{\mathrm{p}}$ was about 10-fold higher than that reported by Bang et al. (1983a). The decrease in $q_{\mathrm{p}}$ at high L-tryptophan concentrations most probably depends on a combination of a reduction in reaction velocity due to high product level and substrate limitation.

In this report we have shown that the biosynthesis of serine limits the production of trypto- 
phan by genetically modified strains of $E$. coli with increased TS activity grown with indole as a precursor. Addition of glycine enhanced the specific productivity twofold. However, such addition to a strain with high level of SHMT did not increase serine and tryptophan production but cell growth was strongly affected. We are now investigating alternative ways to increase serine production in $E$. coli.

We thank M. Johansson for excellent technical assistance.

\section{REFERENCES}

Aiba, S., TsunekaWa, H. \& Imanaka, T. (1982). New approach to tryptophan production by Escherichia coli: Genetic manipulation of composite plasmids in vitro. Applied and Environmental Microbiology 43, 289-297.

Bang, W.-G., LANG, S., SaHM, H. \& Wagner, F. $(1983 a)$. Production of L-tryptophan by Escherichia coli cells. Biotechnology and Bioengineering 25, 9991011.

BanG, W.-G., Behrendt, U., LANG, S. \& Wagner, F. $(1983 b)$. Continuous production of L-tryptophan from indole and L-serine by immobilized Escherichia coli cells. Biotechnology and Bioengineering 25, 10131025.

Bertani, G. (1951). Studies on lysogenesis. I. The mode of phage liberation by lysogenic Escherichia coli. Journal of Bacteriology 62, 293-300.

BIRnBoim, H. C. \& Doly, J. (1979). A rapid alkaline extraction procedure for screening recombinant plasmid DNA. Nucleic Acids Research 7, 1513-1523.

Chemsman, P. \& Crosbie, G. W. (1966). C 1 unit biogenesis in Escherichia coli. Biochemical Journal 99, 24.

Cohen, S. N., Chang, A. C. Y. \& Hsu, L. (1972). Nonchromosomal antibiotic resistance in bacteria: Genetic transformation of Escherichia coli by Rfactor DNA. Proceedings of the National Academy of Sciences of the United States of America 69, 21102114.

CosLoY, S. D. \& McFALL, E. (1970). L-Serine-sensitive mutants of Escherichia coli K-12. Journal of Bacteriology 103, 840-841.

Crosbie, G. W. (1966). Biogenesis of $\mathrm{C}_{1}$ units in Escherichia coli. Biochemical Journal 99, 21-22 p.

Decottignies-Le Maréchal, P., Calderon-Seguin, R., Vandecasteele, J. P. \& Azerad, R. (1979). Synthesis of L-tryptophan by immobilized Escherichia coli cells. European Journal of Applied Microbiology and Biotechnology 7, 34-44.

DEU, J. K. \& HARVEY, R. J. (1982). Sources of one-carbon units in the folate pathway of Escherichia coli. Journal of Biological Chemistry 25, 1980-1986.

GREENE, R. \& RADOVICH, C. (1975). Role of methionine in regulation of serine hydroxymethyltransferase in Escherichia coli. Journal of Bacteriology 124, 269278.

HARVEY, R. J. (1973). Growth and inhibition of protein synthesis in Escherichia coli in presence of trimethoprim. Journal of Bacteriology 114, 309-322.

HERSFIELD, V., BOYER, H. W., YANOFSKY, C., Lovett, M. A. \& Helinski, D. R. (1974). Plasmid Col E1 as a molecular vehicle for cloning and amplification of DNA. Proceedings of the National
Academy of Sciences of the United States of America 71, 3455-3459.

IZUMI, Y., TAKIZAWA, M., TANI, Y. \& YaMaDA, H. (1982). L-Serine production by resting cells of a methanol-utilizing bacterium. Journal of Fermentation Technology 60, 269-276.

KuPERSZTOCH, Y. M. \& HelinsKi, D. R. (1973). A catenate molecule as an intermediate in the replication of the resistance transfer factor $R 6 K$ in Escherichia coli. Biochemical and Biophysical Research Communications 54, 1451-1459.

MeEdel, T. H. \& Pizer, L. I. (1974). Regulation of one-carbon biosynthesis and utilization in Escherichia coli 60653 x. Journal of Bacteriology 118, 905-910.

Miller, J. H. (1972). Experiments in Molecular Genetics. Cold Spring Harbor New York: Cold Spring Harbor Laboratory.

Miller, B. A. \& Newman, E. B. (1974). Control of serine transhydroxymethylase synthesis in Escherichia coli K-12. Canadian Journal of Microbiology 20 , 41-47.

Newman, E. B. (1970). Metabolism of serine and glycine in Escherichia coli K-12. I. Role of formate in the metabolism of serine-glycine auxotrophs. Canadian Journal of Microbiology 16, 933-940.

NeWman, E. B. \& WalkeR, C. (1982). L-Serine degradation in Escherichia coli K-12. A combination of L-serine, glycine and leucine used as a source of carbon. Journal of Bacteriology 151, 777-782.

Newman, E. B., Miller, B. \& Kapoor, V. (1974). Biosynthesis of single-carbon units in Escherichia coli K-12. Biochimica et biophysica acta 338, 529-539.

Newman, E. B., Batist, G., Fraser, J., IsenberG, S., Wegman, P. \&. Kappor, V. (1976). The use of glycine as nitrogen source by Escherichia coli $\mathrm{K}-12$. Biochimica et biophysica acta 421, 97-105.

Newman, E. B., Morris, J. F., Walker, C. \& KAPOOR, V. (1981). A mutation affecting L-serine metabolism in E. coli K-12. Molecular and General Genetics 182, 143-147.

Omori, K., KaKimoto, T. \& Chibata, I. (1983). LSerine production by a mutant of Sarcina albida defective in L-serine degradation. Applied and Environmental Microbiology 45, 1722-1726.

Pizer, L. I. (1965). Glycine synthesis and metabolism in Escherichia coli. Journal of Bacteriology 89, 11451150.

Plamann, M. D., Rapp, W. D. \& Stauffer, G. V. (1983). Escherichia coli K-12 mutants defective in the glycine cleavage enzyme system. Molecular and General Genetics 192, 15-21.

Ream, L. W., Margossian, L., Clark, A. J., Hanson, 
F. G. \& von Meyerburg, K. (1980). Genetic and physical mapping of recF in Escherichia coli $\mathrm{K}-12$. Molecular and General Genetics 180, 115-121.

SCrimgeour, K. G. \& Huennekens, F. M. (1962). Serine hydroxymethylase. Methods in Enzymology 5, 838-843.

Skogman, G., Nilsson, J. \& Gustafsson, P. (1983). The use of a partition locus to increase stability of tryptophan-operon-bearing plasmids in Escherichia coli. Gene 23, 105-115.

Smith, D. H. \& Yanofsky, C. (1962). Enzymes involved in the biosynthesis of tryptophan. Methods in Enymology 5, 794-806.

SPIES, J. R. \& Chambers, D. C. (1948). Chemical determination of tryptophan. Study of color-forming reaction of tryptophan, $p$-dimethylaminobenzaldehyde and sodium nitrite in sulfuric acid solution. Analytical Chemistry 20, 30-39.

StaufFer, G. V. (1983). Regulation of serine, glycine and one-carbon biosynthesis. In Amino Acids Biosyn- thesis and Genetic Regulation, pp. 103-113. Edited by K. M. Herrmann \& R. L. Somerville. London: Addison-Wesley.

Stauffer, G. V., Plamann, M. D. \& Stauffer, L. T. (1981). Construction and expression of hybrid plasmids containing the Escherichia coli gly $A$ gene. Gene 4, 63-72.

TRIBE, D. E. \& PitTARD, J. (1979). Hyperproduction of tryptophan by Escherichia coli: Genetic manipulation of the pathways leading to tryptophan formation. Applied and Environmental Microbiology 38, 181-190.

Tsunekawa, H., Tateishi, M., Imanaka, T.\& Aiba, S. (1981). TnA -directed deletion of the trp operon from RSF2124-trp in Escherichia coli. Journal of General Microbiology 127, 93-102.

UZAN, M. \& DANCHIN, A. (1978). Correlation between the serine sensitivity and derepressability of the ilt genes in Escherichia coli relA- mutants. Molecular and General Genetics 165, 21-30. 